\title{
A Study on the Integration of ICT by EFL Teachers in Libya
}

\author{
Njma Salem ${ }^{1}$, Behbood Mohammadzadeh ${ }^{1 *}$ \\ ${ }^{1}$ Cyprus International University, Lefkosa, NORTHERN CYPRUS
}

Received 28 December 2017 • Revised 15 March 2018 • Accepted 3 April 2018

\begin{abstract}
Given the high importance of adopting ICT into education for developmental purposes in the recent era, the present study is designed to investigate Libyan EFL teachers' attitudes toward ICT adoption in the field of English Language Teaching (ELT). This study looked into attributes (proposed by Rogers, 1995) contributing to adopting ICT, and, more importantly, addressed the relevance of ICT to the socio-cultural context of Libya and adaptations that need to be made for successful adoption and use of ICT. The participants were selected based on availability. The study had a mixed-method design and both quantitative procedures (surveys) and qualitative procedures (interviews) were used to collect data. Both descriptive and interpretive approaches were utilized to analyze data. The analysis led to the identification of a series of problems which were classified into school-level, teacher-level, student level, and system level.
\end{abstract}

Keywords: ICT, adapting and adopting, EFL teacher, Libya

\section{INTRODUCTION}

The highest rate of literacy in the Arab world belongs to Libya (Rhema \& Miliszewska, 2010) which has constantly tried to provide good education for all members of the society regardless of their gender. To keep up with modern advances, some improvements need to be made to the educational system of the country, including the development of Information Communication Technology (ICT) infrastructure which, subsequently, modifies and renews the entire educational process. The adoption of ICT into the educational system, among the other things, includes the development of ICT-oriented curricula and bringing the content to the date. To achieve this goal, first, the obstacles should be identified and removed. The poor condition of the existing infrastructure, unqualified teachers to implement and use of ICT technologies in the classroom, negative attitudes and perceptions about the influence of technology, and lack of access to the internet and technological devices and equipment (BuabengAndoh, 2012; Chen, 2008; Hamdy, 2007; Rhema \& Miliszewska, 2010) are among factors impeding the implementation of ICT in the current education system in developing countries such as Libya. Of these challenges, adopting ICT by all those involved in education that is, students and teachers are of high importance because they are the ultimate users of technology in the educational environment and their acceptance, reactions and attitudes about ICT considerably affect the success of ICT-enhanced education. The present study is an attempt to study these issues in a state university in Libya. We believe that this study will contribute to the literature because adopting ICT to the Libyan educational system provides developments to the country as a whole. CALL-based English language teaching involves new forms of literacies for both students and teachers. The socio-cultural aspect of ICT affects the acceptance of new technology by people including students and teachers in a given country.

\section{THEORETICAL FRAMEWORK}

The term 'ICT' is broadly defined as "forms of technology used for creating, displaying, storing, manipulating, and exchanging information" (Meleisea, 2007, p. 29). Following Collis and Moonen (2001), the application of ICT in education includes a) learning resources (i.e., Educational software, distributed resources via the internet, and video resources); b) instructional organization of learning (i.e., Software and technology tools supporting face-toface lectures, course management systems like Moodle and Blackboard, and computer-based testing system; and

(C) 2018 by the authors; licensee Modestum Ltd., UK. This article is an open access article distributed under the terms and conditions of the Creative Commons Attribution License (http://creativecommons.org/licenses/by/4.0/). \najmasalem123@gmail.com $\boldsymbol{\square}$ behbudm@ciu.edu.tr (*Correspondence) 


\section{Contribution of this paper to the literature}

- $\quad$ Adopting ICT to the Libyan educational system provides developments to the country as a whole.

- CALL-based English language teaching involves new forms of literacies for both students and teachers.

- The socio-cultural aspect of ICT affects the acceptance of new technology by people including students and teachers in a given country.

3) communication (i.e., E-mail system, websites offering communication options for the direct sending for e-mail and forms of structured communication, and software system for text-based chat). The definition offered and the subsequent categorization is too general, hence, for the purpose of the current study ICT is used in a more limited definition to include computer and also the most common type of computer-based technologies such as laptops, tablets, smartphones, and software, and internet-based technologies including email, websites, and social networking sites such as YouTube with the aim of English teaching and learning.

Rogers (1995) Innovation Attributes sub-theory which is also used in this study as a framework explains that perceptions of technology adopters are essential to the innovation-decision process. He suggests that to assess the effect of ICT adoption, users' attitude should be evaluated in the early stages of its implementation. Attitudes have been proposed to contain three components: 1) affective or "a person's evaluation of, liking of, or emotional response to some object or person", 2) cognitive or "a person's beliefs about, or factual knowledge of, the object or person", and 3) behavioral or "he person's overt behavior directed toward the object or person" (Gordon, 1969, pp. 24-25). Rogers' postulates that teachers' and students' attitudes and perceptions towards innovation should be examined with respect to five perceived attributes of innovations including 1) advantage, 2) compatibility, 3) complexity, 4) trialability, and 5) observability.

\section{Adoption vs Adaption}

Mariam Webster Dictionary (2017) defines 'adopt' as "to take for one's own use (something originated by another)" and 'adaptation' as to "change (something) so as to make it suitable for a new use or situation". Applying the same notions to the context of the present study 'adoption' refers to starting to incorporate technology in educational contexts to get benefits of its potentials in foreign language education. The incorporation of adoption of technology however, requires a further step, that of adaptation, which refers to making the requisite changes in the educational settings (such as, provision of the infrastructure) to pave the way for successful integration of technology.

\section{Factors Affecting the Adoption of ICT}

According to Rogers (2003) adoption is a decision that an individual makes concerning the use of an innovation as the best course of action available. There are different factors those affect the adoption and adoption of ICT into teaching and learning. These factors are personal characteristics including educational level and experience, age, gender, educational experience, prior experience of applying ICT tools for educational purposes, overall attitude and perceptions towards ICT tools (Abukhattala, 2016; Drent \& Meelissen, 2008; Hismanoglu, 2012; Liaw, Huang \& Chen, 2007), computer self-efficacy (Rohatgi, Scherer, \& Hatlevik, 2016; Yuen \& Ma, 2008), teaching experience (Osei, Larbi, Osei-Boadu, 2014), institutional characteristics including technology accessibility (Usluel, Askar \& Bas, 2008), technical support (Korte \& Husing, 2007; Yilmaz, 2011), professional development (Hsu, 2016; Mishra \& Koehler, 2006), technological characteristics (Albirini, 2006; Martins, Steil \& Todesco, 2004), and sociocultural factors (Li, 2002; Liu, 2009).

\section{Teachers' Perception into ICT Adoption in Language Education}

A common line of research during the last decades have focused on teachers' and students' attitudes on different aspects of ICT adoption. For instance, Hismanoglu (2012) studied prospective EFL teachers' attitudes about implementation of ICT in the distance higher education system. Majority of the teachers were found to hold negative attitudes to ICT adoption despite having basic computer skills; however, they believed that ICT tools are effective tools for acquiring a good deal of new things (also see Tri \& Nguyen, 2014). In the context of Libya, Abukhattala (2016) studied pre-service English language teachers' readiness to integrate technology in some high and secondary schools in Misurata, Libya. The findings indicated that although all the participants were willing to use technology to teach English as a foreign language, they realized some barriers to achieve this goal including lack of funding, scarcity of technological equipment in schools and lack of proper training to use technology.

Another strand of research have concentrated on identifying factors that affect the adoption of ICT in a variety of contexts. Liu (2009) investigated Chinese non-English major students' attitudes toward the adoption of ICT into 
English language learning to identify factors affecting the adoption of technology in foreign language education. The findings indicated that the participants had different attitudes about ICT integrating due to factors including ICT attributes, cultural perceptions, computer experience and ICT confidence. In another study, Tri and Nguyen (2012) found that according to the students, the frequency of using ICT was of importance.

Several studies have shown that language teachers have identified several benefits of ICT adoption (Keller, 2000; Zhou, 2003). Generally speaking, the findings of the studies suggest that the more positive are users about ICT adoption, the higher is the probability of attempting to integrate it ( $\mathrm{Hu}, \mathrm{Clark} \& \mathrm{Ma}, 2003)$.

Moreover, as ICT is developed and implemented in developed countries, its adoption in developing countries like Libya may raise some challenges including resistance against its adoption, because as Rogers (1995) argues cultural/social norms of a country contribute to the acceptance or rejection of a given technology among its people. Despite its significance, very few studies have studied the influence of sociocultural factors. As an example, Li (2002) carried out a about the influence of a local culture related to the use of Internet by students according to Chinese and British students' perceptions. Several cultural differences were found that there were some discriminations between the Chinese and British students in terms of Internet experience, attitudes, usage, and competence.

As the literature review suggests most of the studies investigating teachers' perceptions have been conducted in contexts other than Libya. The available studies have also yielded contradictory results suggesting both positive and negative perceptions about ICT adaptation. It was also observed that only a few studies have addressed the cultural suitability (Thomas, 1987) of ICT. More importantly, the adaptations required to make the context ready for accepting ICT have been the subject of a very few studies. To the best of the author's knowledge, these gaps have not been addressed in the educational context of Libya before. As far as ICT is concerned, some researchers such as Sarfo and Ansong-Gyimah (2010) assert that different perceptions on the part of students, teachers, and education officers can lead to unproductive learning. Thus, the present study is an attempt to investigate these gaps in more depth.

\section{Objectives and Research Questions}

The present study is designed to investigate EFL teachers' attitudes toward ICT adoption and adaptation in the field of English Language Teaching (ELT). The study also aims to identify attributes (proposed by Rogers, 1995) contributing to adopting ICT, and also the relevance of ICT to socio-cultural context of Libya and adaptations that need to be made for successful adoption and use of ICT. To be specific, the study seeks answer to the following questions:

1. What are the teachers' overall attitude about ICT adoption in education?

2. What are the major attributes of ICT as identified by the teachers?

3. What are the cultural relevance of ICT tools to norms of Libyan education as identified by the teachers?

4. What are the requirements of ICT to match the socio-cultural context of Libya according to the teachers' view?

\section{METHODOLOGY}

The present study was administered in Tripoli University in Tripoli, Libya, Faculty of education, Department of English language. It is the largest university in Libya with a population of over 115,000 students. Although this university was selected through convenience sampling, another important reason underpinning the selection of this university was that it is one of the universities which is equipped with basic ICT infrastructure while most of the other education centers still lack ICT infrastructure because implementation of ICT in Libya is still in its early stages in the context of Libya. Thus, the researcher assumed that teachers who have experienced working with ICT tools can provide more valuable information concerning the benefits and drawbacks of ICT adoption as well as the required adaptations in this setting.

\section{PARTICIPANTS}

The participants for this study are 32 teachers in the Faculty of Art and Education in University of Tripoli, the largest state university in Libya. Based on their availability, the teachers were selected through convenience sampling but their participation in the presents study was voluntary. The demographic and educational characteristics of the participants is given below.

Most of the teachers were within 36-above $(\mathrm{N}=12,37.5 \%)$ and 31-35 $(\mathrm{N}=10,31.2 \%)$ years of age, respectively. One fourth $(25 \%)$ of the teachers were between $26-30$ and only 2 teachers $(6.2 \%)$ who were almost new teachers 
were between $22-25$ years old. The majority of the teachers $(\mathrm{N}=23,71.8 \%)$ had a master's degree and $9(28.1 \%)$ had a PhD degree, all in English Language Teaching.

With regard to the teaching profession, an equal proportion of teachers (31.2\%, N=10), had 1-5, and 11-15 years of teaching experience, respectively, and $37.5 \%(\mathrm{~N}=12)$ had between 6-11 years of teaching experience. Concerning their approach to teach English, the teachers reported using a variety of teaching methods. All the teachers (100\%) reported using 'lecturing' and 93.7\% reported 'active discussion' as their most frequently used methods. Twentyone $(65.6 \%), 16(50 \%)$, and $13(40.6 \%)$ of the teachers reported 'collaborative activities', 'active discussion', and 'demonstration' as the methods used for teaching English by them. 'computer-assisted instruction' was one of the least reported methods reported by only 4 teachers (12.5\%). Role-playing was the least reported strategy reported by only 2 teachers $(6.2 \%)$. Six teachers $(18.7 \%)$ specified other methods including translations as additional teaching methods they use.

Concerning ICT technology, only 4 teachers (12.2\%) had already attended ICT classes with 28 teachers $(87.5 \%)$ having no training on how to use ICT technologies or other technological tools. Most of the teachers $(\mathrm{N}=30,93.7 \%)$ had ICT tools at home while just $2(6.2 \%)$ could get access to the ICT tools at university because they had no such tools at home. No teacher $(0 \%)$ had to use other sources such as internet cafes in order to access computer. Very few students $(\mathrm{N}=5,3.2 \%)$ accessed technological ICT tools from other places like cafes. As far as ICT competency is concerned, half of the teachers $(\mathrm{N}=16,50 \%)$ reported having a moderate ICT competence and $14(43.8 \%)$ reported having little ICT competence. Only two teachers (6.2\%) reported their ICT competence as high.

\section{INSTRUMENTS}

Different instruments were implemented in the current study:

\section{Demographic Information Form}

This form is designed to elicit information about characteristics of the participants (age, gender, years of teaching experience, etc.)

\section{Adoption of ICT Questionnaires}

This is a questionnaire originally developed by Albirini (2006) to address Syrian EFL teachers' attitudes towards ICT adoption in high schools. The questionnaire has three scales. The first section of the questionnaire (items 1-20) addresses teachers' overall attitudes about ICT. The items are designed to measure the affective domain of computer attitude (items 1-6), cognitive domain (items 7-15), and behavioral domain (items 16-20). The Cronbach's alpha of this section in Albirini's study was (0.90). The second section (18 items) questions teachers' perception into computer attributes (advantage, compatibility, complexity, trialability, and observability). The Cronbach's alpha of this section in Albirini's study was (0.86). The third section of the questionnaire surveys the teachers' perception of the relevance of ICT adoption to the sociocultural context of the society and education. The Cronbach's alpha of this section in Albirini's study was (0.76). All the scales are scored on a 5-point Likert-type scale.

\section{Semi-structured Interview}

A group of teachers voluntarily participate in the interview and answer some questions prepared in form of a checklist of open questions.

\section{DESIGN}

This study had a descriptive exploratory nature and this approach is suitable when, as asserted by Creswell et al. (2003), little is written on the topic or the people under investigation. In fact, very few studies have addressed the adoption and adoption of ICT in Libyan settings.

This study used a mixed-method design to address the questions under investigation. The importance of mixedmethod approaches have been recognized by some scholars (e.g., Brown \& Rodgers, 2002; Johnson \& Onwuegbuzie, 2004).

\section{PROCEDURE}

The present study was conducted during 2016-2017 academic year. In order to implement the study, a letter was prepared by the researcher and signed by the director of the English department as a support letter to the administration of the study and collecting data from the Department of English Language. The acceptance letter was acquired. Then, to establish reliability of the adopted questionnaire from Albirini, the questionnaire was first 
Table 1. Descriptive statistics of the teachers' responses in the three domains of the overall attitude scale

\begin{tabular}{cccccc}
\hline Domains & Groups & N & Mean & SD & Std. Error Mean \\
\hline Affect & Teachers & 32 & 4.11 & 0.416 & 0.073 \\
\hline Cognitive & Teacher & 32 & 4.1 & 0.339 & 0.059 \\
\hline Behavioral & Teachers & 32 & 4 & 0.538 & 0.095 \\
\hline
\end{tabular}

piloted with 30 participants. To this end, the EFL teachers in the department of English language were informed and briefed about the purpose of the study.

In the next step, to implement the real study, a number of 34 teachers' surveys were directed in English classes during a week. Following Dillman's (1978) recommendations, a letter of informed consent, accompanied the questionnaire which itself consisted of the demographic information form of the participants and the three scales. A group of 32 survives have been gathered from the teachers with the acceptance rate of $94.1 \%$.

Thereafter, teachers were recruited for participation in the interview which aimed to elicit information about the perceived adaptations in the current ICT to make it fit the Libyan education system.

\section{DATA ANALYSIS PROCEDURE}

The quantitative data collected from the student and teachers questionnaires was analyzed via Statistical Package for Social Sciences (19.0) by performing descriptive statistics while the frequency and percentage of the information in the demographic information form, and Mean (M) and Standard Deviation (SD) of the responses to the questionnaire items and components of each scale were computed.

Qualitative data collected from the audio-recorded interviews administered to some of the participants were transcribed by the researcher and analyzed using an interpretive approach (Lincoln, 1995). To this end, the transcripts were analyzed and several themes were identified by the researcher. However, to ensure validity and to reduce subjectivity, the transcripts were also analyzed by one of the English assistant professors at Tripoli University and areas of mismatch were solved through negotiation so the problems were appropriately placed in school-level, teacher- level and system-level.

\section{RESULTS}

\section{Teachers' Overall Attitudes toward ICT}

As indicated in the previous sections, teachers completed the Overall Attitude Scale.

Table 1 shows the mean and SD of teachers' responses to the items of the overall attitude scale. Table 4 highlights that in the affect section, teachers do not afraid of ICT tools $(\mathrm{M}=4.2)$, feel comfortable with ICT tools (M $=4.2$, and are satisfied with the presence of ICT tools $(\mathrm{M}=4.1)$. However, in case of the next three items, the teachers reported positive attitudes. The teachers dislike discussions related to ICT technologies with other people tools $(\mathrm{M}=3.8)$, ICT tools appear grateful to them $(\mathrm{M}=4.1)$, and like ICT be used for teaching $(\mathrm{M}=4.1)$.

With regard to the cognition domain, teachers are a little more agreed that ICT tools can enhance students' learning $(M=4.4)$, are appropriate tools for serviceable and accelerated way for acquiring knowledge $(M=4.2)$, save time and effort $(M=4.0)$, and make schools a better place $(M=3.9)$. 
Table 2. Mean and SD of the teachers' responses to the items of the overall attitude scale

\begin{tabular}{lll}
\hline & Mean & SD \\
\hline Affective Domain & 4.2 & 0.97 \\
\hline 1. ICT tools do not scare me at all & 0.63 \\
\hline 2. ICT tools do not make me feel uncomfortable & 4.2 & 0.75 \\
\hline 3. I am glad there are more ICT tools these days & 4.1 & 1.02 \\
\hline 4. I do not like talking with others about computers & 0.73 \\
\hline 5. Using ICT tools is enjoyable & 3.8 & 0.88 \\
\hline 6. I dislike using ICT tools in teaching & 4.1 & 0.78 \\
\hline Cognitive Domain & 4.1 & 1.05 \\
\hline 7. ICT tools are suitable means for saving time and effort & 0.85 \\
\hline 8. Without the presence of ICT tools, learning institutes would be better & 0.9 \\
\hline 9. ICT tools should be used with all subject matters & 4 & 0.94 \\
\hline 10. To learn about ICT means to waste our time & 3.9 & 0.91 \\
\hline 11. ICT tools would motivate students to do more study & 4 & 0.93 \\
\hline 12. ICT tools are appropriate means of getting information & 4.1 & 0.75 \\
\hline 13. I believe that I can teach without ICT tools & 3.9 & 0.92 \\
\hline 14. ICT tools can enhance students' learning & 4.2 & 1.01 \\
\hline 15. ICT tools do more harm than good & 4 & 0.87 \\
\hline Behavioral Domain & 4.4 & 0.92 \\
\hline 16. I prefer to do some tasks by hand and not by ICT tools & 4 & 0.84 \\
\hline 17. I would buy ICT tools if I had enough money & 0.92 \\
\hline 18. I would avoid ICT tools as much as possible & 3.8 & \\
\hline 19. I would like to learn more about computers & 4 & 3.9 \\
\hline 20. I have no intention to use ICT tools in the near future & 4 & 4.2 \\
\hline
\end{tabular}

Table 3. Descriptive statistics of the teachers' results in the attributed of ICT

\begin{tabular}{cccccc}
\hline Attributes & Group & N & Mean & SD & Std. Error Mean \\
\hline Advantage & Teachers & 32 & 4 & 0.34 & 0.06 \\
\hline Compatibility & Teacher & 32 & 4 & 0.44 & 0.078 \\
\hline Complexity & Teachers & 32 & 4.1 & .39 & 0.07 \\
\hline Observability & Teachers & 32 & 4.2 & 0.36 & 0.063 \\
\hline
\end{tabular}

In the behavioral domain, teachers agreed that they would avoid ICT tools more than as much as possible $(\mathrm{M}=$ 3.9). It is noteworthy that despite minor differences in the mean scores of some items responded by the teachers and students, the differences are not statistically significant suggesting that the teachers and students share almost similar overall attitudes about ICT.

\section{Teachers' Identified Attributes of ICT}

The respondent teachers in the current study were surveyed about the four major attributes of ICT.

Table 3 shows the mean and SD of teachers' response to the items of the computer attitude scale to provide a more detailed explanation of the results. In terms of the relative advantage of computers, teachers reported that ICT tools can improve education $(\mathrm{M}=4.1)$ and enhance the quality of students' learning $(\mathrm{M}=.4 .1)$, their presence in the classroom makes learning the content very enjoyable $(M=3.5)$, and they are beneficial for learning language $(\mathrm{M}=3.9)$. However, in terms of item 2 , that is, teaching with ICT tools offers real advantages over traditional methods of instruction, teachers $(\mathrm{M}=.4 .1)$, probably due to the fact that teachers who are familiar with different teaching methods are in a better position to recognize the merits of technology-based approaches over the traditional teaching approaches.

Regarding the second attribute or compatibility with teaching practices, the responses were as follows: using ICT tools is suitable for providing a favorable way of learning to students $(M=4.0)$. And, its use proper for many activities those are related to learning languages $(\mathrm{M}=4.1)$.

Fitting of computer use into curriculum goals $(M=4.0)$ and limited class time for computer use $(M=3.8)$. In contrast, the teachers did not strongly agreed that ICT tools have a place in schools $(\mathrm{M}=3.9)$.

In terms of complexity attribute, teachers' rate of agreement with items 11 and 12 was a little high. These two items maintained that 'It would be hard for me to learn to use the computer in teaching' $(\mathrm{M}=3.9)$ and having no problem in knowing about the primary operations of ICT tools $(M=4.1)$. Teachers and shared the idea that ICT tools make my teaching role confused during in-class duties (Item 13, M = 3.9). However, ease of working with ICT 
Table 4. Mean and SD of teachers' responses to the items of the computer attribute scale

\begin{tabular}{|c|c|c|}
\hline & Mean & SD \\
\hline \multicolumn{3}{|l|}{ Advantage } \\
\hline 1. ICT tools will improve education & 4.1 & 0.62 \\
\hline 2. Teaching with ICT tools offers real advantages over traditional methods of instruction & 4.1 & 0.57 \\
\hline 3. Computer technology cannot improve the quality of students' learning & 4.1 & 0.75 \\
\hline 4. Using computer technology in the classroom would make the subject matter more interesting & 3.5 & 1 \\
\hline 5. ICT tools are not useful for language learning & 3.9 & 0.8 \\
\hline \multicolumn{3}{|l|}{ Compatibility } \\
\hline 6. ICT tools do not have a place in schools & 3.9 & 0.89 \\
\hline 7. Computer use fits well into my curriculum goals & 4 & 0.78 \\
\hline 8. Class time is too limited for computer use & 3.8 & 0.95 \\
\hline 9. Computer use suits my students' learning preferences and their level of computer knowledge & 4 & 0.81 \\
\hline 10. Computer use is appropriate for many language learning activities & 4.1 & 0.9 \\
\hline \multicolumn{3}{|l|}{ Complexity } \\
\hline 11. It would be easy for me to learn to use the computer in teaching & 3.9 & 0.94 \\
\hline 12. I have no difficulty in understanding the basic functions of computers & 4.1 & 0.73 \\
\hline 13. ICT tools make my teaching activities complicated & 3.9 & 0.73 \\
\hline 14. It is possible for everyone to learn to use ICT tools & 4.4 & 0.75 \\
\hline \multicolumn{3}{|l|}{ Observability } \\
\hline 15. I have never seen ICT tools at work & 4 & 0.92 \\
\hline 16. ICT tools are considered as sufficient teaching tools all over the world & 3.9 & 0.73 \\
\hline 17. I have not observed ICT tools used for educational purposes & 4.1 & 0.79 \\
\hline 18. I observed some Libyan EFL teachers use ICT tools for teaching & 4.7 & 0.42 \\
\hline
\end{tabular}

Table 5. Descriptive statistics of the teachers' results for the identified sociocultural relevance of ICT

\begin{tabular}{cccccc}
\multicolumn{7}{l}{ Table 5. Descriptive statistics of the teachers' results for the identified sociocultural relevance of ICT } \\
\hline Group & N & Mean & SD & Std. Error Mean \\
\hline Cultural relevance & Teachers & 32 & 3.88 & 0.254 & 0.045 \\
\hline
\end{tabular}

tools (item 14) was an issue highly agreed by the teachers $(\mathrm{M}=4.4)$ indicating that the teachers probably have higher ICT knowledge.

Lastly, teachers' responses on the observability attribute indicates the same percentage of agreement with items 16 and $17(M=3.9)$. Nevertheless, less teachers more reported seeing ICT tools at work (item 15) $(M=4.0)$. On the other hand, more teachers reported observing ICT tools at work in the Libyan educational context (4.7). It is of note that this item $(18)$ was the most strongly agreed item of all $(\mathrm{M}=4.7)$.

\section{Teachers' Recognized Sociocultural Relevance of ICT}

Teachers were surveyed to find out the relation between ICT and the social and cultural norms of Libya.

The items indicate that knowing how to use ICT is needed by students for their future carriers $(\mathrm{M}=4.4)$, ICT tools are suitable for improving our lives $(\mathrm{M}=4.0)$, the use of ICT tools does not mean that the Arab people will forget about leaning their own traditions $(\mathrm{M}=4.0)$, the ones who are professional at using ICT tools are advantageous over the who are not $(\mathrm{M}=4.0)$, and the wide spread of ICT tools have the advantage of making the life easier $(M=4.0)$. To a lesser degree but by similar rates, the teachers also agreed with the fact that the ICT tools that are needed should be those which are appropriate for the Arab identity and culture $(\mathrm{M}=3.9)$, and the idea that students like to be taught by human teachers than to be taught by ICT tools $(M=3.5)$.

To elaborate, the mean scores of the responses were high regarding items 1, 8, 10 and 16 . The teachers agreed that ICT tools do not have the ability to make their schools, classes and lives different $\mathrm{M}=3.8)$, 'ICT tools are proliferating too fast' $(\mathrm{M}=4.0)$, using ICT tools make us depend on foreign countries $(\mathrm{M}=3.3)$, and 'ICT tools should be a priority in education' $(\mathrm{M}=4.2)$. 
Table 6. Mean and SD of teachers' responses to items of the cultural perception scale

\begin{tabular}{llc}
\hline & Mean & SD \\
\hline 1. ICT tools will not make any difference in our classrooms, schools, or lives & 0.98 \\
\hline 2. Students need to know how to use ICT tools for their future jobs & 3.8 & 0.66 \\
\hline 3. Students prefer learning from teachers to learning from computers & 4.4 & 0.71 \\
\hline 4. Knowing about ICT tools earns one the respect of others & 3.5 & 0.98 \\
\hline 5. We need ICT tools that suit better to the Arabic culture and identity & 3.7 & 0.71 \\
\hline 6. ICT tools can make our lives better & 3.9 & 0.68 \\
\hline 7. ICT use will not prevent Arab people from knowing about their own culture & 4 & 0.78 \\
\hline 8. ICT tools are expanding very quickly & 4 & 0.76 \\
\hline 9. Being skillful at ICT means being more privileged over others & 4 & 0.73 \\
\hline 10. ICT tools will make us depend more on the foreign countries & 4 & 0.7 \\
\hline 11. Some social issues should be focused on before the integration of ICT in the & 3.3 & 0.8 \\
educational system & 3.7 & 0.94 \\
\hline 12. Our lives are becoming easier because of the rapid development of ICT & 4 & 0.59 \\
\hline 13. ICT tools dehumanize society & 3.2 & 0.91 \\
\hline 14. Working with ICT tools does not diminish people's relationships with one other & 4.3 & 1 \\
\hline 15. ICT tools encourage unethical practices & 3.5 & 4.2 \\
\hline 16. ICT tools should be a priority in education & & \\
\hline
\end{tabular}

Table 7. Teachers' recognized problems with the current ICT in Libya and the required adaptations

\begin{tabular}{|c|c|c|c|}
\hline Problems & Mentioned by & Description of the problem & Adaptations \\
\hline \multicolumn{4}{|l|}{ School-level } \\
\hline Poor funding of education & Teachers & $\begin{array}{c}\text { With the exception of some major educational } \\
\text { centers, Libya's education system is yet } \\
\text { unfunded. }\end{array}$ & $\begin{array}{l}\text { - Assigning more budget to the } \\
\text { education sector }\end{array}$ \\
\hline \multirow{2}{*}{$\begin{array}{l}\text { Inadequate ICT } \\
\text { infrastructure }\end{array}$} & \multirow{2}{*}{ Teachers } & \multirow{2}{*}{$\begin{array}{l}\text { Little attempt has been made to build ICT } \\
\text { infrastructure so the educational centers can be } \\
\text { equipped with ICT facility. }\end{array}$} & $\begin{array}{c}\text { - Developing adequate ICT } \\
\text { infrastructure }\end{array}$ \\
\hline & & & $\begin{array}{l}\text { Providing related hardware } \\
\text { and software equipment. }\end{array}$ \\
\hline \multicolumn{4}{|l|}{ Teacher-level } \\
\hline \multirow[b]{2}{*}{ Lack of skilled teachers } & \multirow[b]{2}{*}{ Teachers } & \multirow{2}{*}{$\begin{array}{c}\text { Most institutions in Libya lack computer-literate } \\
\text { teachers or ICT experts who can support and } \\
\text { manage the internet process. }\end{array}$} & $\begin{array}{l}\text { - Inclusion of ICT courses in } \\
\text { teacher training programs }\end{array}$ \\
\hline & & & $\begin{array}{c}\text { - Incorporating mandatory } \\
\text { computer training programs for } \\
\text { teachers } \\
\end{array}$ \\
\hline $\begin{array}{l}\text { Resistance towards } \\
\text { innovation }\end{array}$ & Teachers & $\begin{array}{l}\text { Some teachers are not willing to change from } \\
\text { their traditional pedagogical approaches. }\end{array}$ & $\begin{array}{l}\text { - Assigning incentives to } \\
\text { teachers who incorporate } \\
\text { technology to their practices }\end{array}$ \\
\hline \multicolumn{4}{|l|}{ System-level } \\
\hline \multirow{2}{*}{$\begin{array}{l}\text { Inadequate teaching } \\
\text { materials }\end{array}$} & \multirow{2}{*}{ Teachers } & \multirow{2}{*}{$\begin{array}{l}\text { The teaching materials and assignments are not } \\
\text { computer-based and do not comply with the } \\
\text { current teaching practices. }\end{array}$} & $\begin{array}{l}\text { - New ICT-based materials } \\
\text { need to be developed. }\end{array}$ \\
\hline & & & $\begin{array}{l}\text { - Teachers should be allowed to } \\
\text { develop their own materials. }\end{array}$ \\
\hline $\begin{array}{l}\text { Inflexibility of the } \\
\text { traditional education } \\
\text { system }\end{array}$ & Teachers & $\begin{array}{l}\text { Teachers have to follow the restrictive curricula } \\
\text { of the institution in which they work. }\end{array}$ & $\begin{array}{l}\text { - The traditional system should } \\
\text { give way to newer teaching } \\
\text { approaches which allow ICT- } \\
\text { based instruction. }\end{array}$ \\
\hline
\end{tabular}

Teachers' agreement with 4, 11, 13, 14, and 15 was high. These items maintain that having ICT knowledge can make the person more respected by others $(M=3.7)$, some social issues need to be focused on before the integration of ICT in education $(M=3.7)$, 'ICT tools dehumanize society' $(M=3.2)$, using ICT tools do not destroy the relationships between people $(\mathrm{M}=4.3)$, and 'ICT tools encourage unethical practices' $(\mathrm{M}=3.5)$.

\section{Teachers' Perceived ICT Adaptations}

Following Balanskat et al. (2007), the problems identified by the teachers were categorized in three levels.

At the school level, teachers pointed to the problem of inadequate ICT infrastructure, and to solve this problem they suggested the development of ICT infrastructure and provision of more hardware and software equipment. They also recognized an additional problem, that is, poor funding of education which can be solved by assigning 
more budget to education at schools. At the teacher-level, the problems are related to lack of computer skill and resistance to computer, and the solutions include inclusion of ICT courses in the curriculum and provision of computer literate teachers.

At the system-level, one of the problems recognized teachers is related to inadequate teaching materials. Moreover, teachers believed that they should be allowed to develop their own materials. Another problem mentioned by the teachers was the inflexibility of the traditional education system.

\section{DISCUSSION}

\section{Teachers' Overall Attitudes about ICT}

The results of teachers' overall attitudes about ICT in one of the major universities in Libya indicated that teachers were positive about its adoption in the educational setting. These findings are consistent with the findings of some other studies (Abukhattala, 2016; Drent \& Meelissen, 2008) but in contradiction with some others (Sarfo \& Ansong-Gyimah, 2010).

When teachers find the place of ICT promising, and recognize it as a valuable means of promoting teaching and learning, they are more inclined to adopt it and use it if ICT tools are available to them. It is noteworthy that high optimism about the effect of ICT (e.g., Becta, 2008; Hismanoglu, 2012) by teachers increases the possibility of its adoption (Hew \& Brush, 2007). Also, Nneji (2014) argues that human has cognitive, affective, and psychomotor (behavioral) domains which are also representative of the dimensions of the overall attitude scale but teachers should know that all these cannot be fully developed through ICT in education.

\section{Teachers' Identified Attributes of ICT}

Computer attributes are strong predictors of the adoption of ICT tools for teaching and learning purposes (Albirini, 2006; Martins et al., 2004). The mean scores indicated that the teachers were overall optimistic about the advantage of ICT tools and its contribution to education, quality of learning, and learning different subject matters. Using ICT tools as a medium of instruction and its pedagogical effectiveness has long been debated. The results of many studies suggest that the high performance of students in classes where ICT is incorporated are usually overestimated and the gains are mainly due to the novelty of the instruments, content or methods rather than incorporation of ICT; that is why, in many contexts students still prefer to be taught traditionally by their own teachers rather than through the help of ICT tools probably because teachers are agents which can change lives of the students rather than vehicles to deliver course content. Moreover, presence of teachers, and direct teacherstudent relationship has many positive effects on the teaching and learning process such as its effect on students' motivation (Nneji, 2014), thus, teachers cannot be replaced by computers. In terms of, observability, more teachers reported observing ICT tools at work in the Libyan educational context (4.7). Indeed, teachers agreed with the item, yet, they had seen ICT incorporated and used at different places. Observability and advantage were the most important attributes for adopting technology in Martins et al. (2004), and Albirini (2006) studies, respectively.

Regarding the attributes of compatibility and complexity, teachers specifically believed that ICT tools are preferable learning means for students and suitable for their ICT knowledge and they are also suitable for different activities for language learning. The participants also showed their agreement with the fact that they find it not difficult to understand the primary functions of ICT tools, however, learning the use of ICT tools in real teaching practices is not an easy task. The ease of working with ICT tools was an issue highly agreed by the teachers indicating that the teachers probably have high ICT knowledge. These findings are consistent with the results found by other researchers indicating inadequate ICT knowledge of teachers and students in other contexts (Hatlevik Guðmundsdóttir, \& Loi, 2015; Mingaine, 2013).

These findings show that successful incorporation and use of computer technologies cannot be limited to understanding the basic functions of computers; rather teachers need to acquire ICT knowledge specific to a particular content domain and functions required for teaching purposes and performing the academic activities. In other words, teachers need to develop ICT competence. Technological Pedagogical Content Knowledge or TPACK is specifically emphasized as a knowledge that $21^{\text {st }}$ century teachers should develop (Hsu, 2016; Thomson \& Mishra, 2007). It is of note that adequate ICT knowledge also results in computer self-efficacy or capability to use ICT by teachers (Aesaert \& Braak, 2014; Peralta \& Costa, 2007; Rohatgi et al., 2016; Yuen \& Ma, 2008).

When teachers develop sufficient awareness about the computer attributes, the adoption and application of ICT in education is facilitated (Rogers, 2003). 


\section{The Perception of Teachers about the Relevance of ICT to the Sociocultural Norms of the Libyan Society}

The results of the teachers' responses to sociocultural relevance of ICT scale was found to be almost similar indicating that cultural factors play an important role concerning the adoption and adoption of ICT in Libya as recognized by the teachers. To provide a more in-depth analysis, teachers' responses are discussed with respect to every single item of the scale. The majority of the teachers overall recognized ICT tools compatible with Libyan society and education system, as well as a vehicle for enhancing living standards and facilitating living in general. They also considered it as a privilege contributing to finding better future jobs. Also, teachers moderately agreed with the need for ICT tools that are suitable for the culture and identity of Arabic societies, and the students' willingness to learn from real teachers over ICT tools. Indeed, there has always been uncertainty about the positive influence of ICT tools on academic improvement as perceived by teachers in this study. This has also been argued and proved by several researchers (Nneji, 2014).

Moreover, despite current arguments concerning the negative contribution of ICT to societal values (Nneji, 2014), teachers in this study believed that using ICT tools will not interrupt the Arabic people from learning about own traditions and working with ICT tools would not decrease the relationships between people, and do not dehumanize society, and it is important to take into consideration some other social norms before the implementation of ICT into the educational system. Teachers were almost neutral about the fact that ICT tools can decrease their independence and foster unethical practices similar to the findings of some other studies (Liu, 2009).

It is argued that the relationship between humans and their environment is not artificial, advent of ICT has caused education to lose its social aspect so that today, "Social disorientation is one of the pseudo aims or counter aims of education in this postmodern era" (Nneji, 2014, p. 91), and even if they are to be incorporated, the system of norms should be clarified (Rogers, 2003). Computer technologies also have the potential to impose some hidden agendas and certain cultural and moral values (Johnson, 2004); that is why even in the presence of teachers' agreement with its adoption, further social issues should be taken into account (Rogers, 2003; Thomas, 1987).

\section{Teachers' Perception of the Required ICT Adaptations}

The teachers' perceived problems hindering the adoption of ICT in Libya and the perceived modifications which can be made to facilitate its adoption indicated that such problems were related to all levels.

At the school level, the fact that teachers pointed to inadequate ICT infrastructure and they recognized the poor funding of education which shows that teachers can look at some problems at a more profound level. Moreover, teachers pointed to the underlying reason or lack of budget which is the underlying reason for this deficiency, i.e., poor infrastructure, etc.

It was also found out that poor ICT competence was the teachers' problem (Al-Oteawi, 2002; Hatlevik et al., 2015), and resistance to computer suggesting that the new generations are more open to computer technologies compared to older generation who find acquiring computer skills demanding (Watson, Proctor, Finger, \& Lang (2005). Of course, as reported by the teachers, inclusion of ICT courses in the curriculum and provision of computer literate teachers who can help them to do computer-based assignments which also leads to teachers' professional development (Hsu, 2016; Lawless \& Pellegrino, 2007), and assigning incentives to teachers who incorporate technology to their practices for the latter problem could solve this problem.

\section{CONCLUSION}

Given the widespread use of technology in the $21^{\text {st }}$ century and its increasing application in the education system, schools in developing countries have initiated incorporating ICT tools more recently. Libya as one of these countries launched the incorporation of ICT in some of the Libyan institutes of higher education few years ago. Although ICT in education in Libya still appears to be in its infancy and e-learning in Libya is still struggling with many challenges, the very attempt to incorporate ICT to education has provided a chance implement e-learning for the different educational levels specifically the higher education. Yet, there are important points that should be taken into account as explained below.

The mere provision of ICT structure and ICT tools for schools does not cultivate the belief of the need for its adoption among people who use such tools. Therefore, the study of teachers' attitudes contributes a lot to the implementation of ICT plans since teachers are strongly influenced by new technologies. That is why Sheingold (1991) believes that adopting technology to the educational system is considered a difficult because of human users rather than because of the technology itself.

Another major point to consider is that, this study brought together a comprehensive picture of the factors affecting the adoption and adaptation of ICT in Libya. The factors identified appear to be interrelated thus this 
process should be viewed holistically. To elaborate, the barriers identified in this study appear to affect one another. For instance, lack of accessibility to ICT tools discourages teachers to use them so they do not develop appropriate ICT knowledge and skills and try to resist against it. Non-inclusion of ICT into teaching practices, consequently, results in fostering students who lack ICT competence and resist against e-learning. In another circumstance, teachers might have sufficient accessibility to ICT tools but lack of ICT-related training programs may prevent them from making the best using ICT for pedagogical purposes. The findings from the study yielded some useful implications for all stakeholders involved in ICT adaptation and adoption in Libya. In this section, recommendations which improves the adoption and adaptation of ICT in education environment are presented.

\section{IMPLICATIONS}

Investment for ICT infrastructure and ICT tools: The absence of technology is one of the major barriers in the implementation of ICT. The country addressed in this study is Libya which has started some investments to foster ICT in education. The evidence shows that although some educational settings have ICT infrastructure, they still confront serious barriers concerning availability of hardware, internet access, technical support, etc. So, scarcity of qualified hardware equipment and appropriate software for educational purposes is a main preventer of the development of the educational ICT in the future. For instance, the availability of poorly maintained ICT tools or inappropriate educational software are more troublesome than being useful because they can disrupt even the best planned lessons (Becta, 2006).

It is worth mentioning that, in addition to ICT investment, one of the basic goals of the local ICT policy implemented in Libya since 2005 is investment in human resources without which ICT strategy cannot be implemented. Currently, an acute scarcity of ICT qualified teachers who should incorporate ICT in classrooms and also educate technically qualified students, are felt (Hamdy, 2007) but the country is trying hard to equip all universities with ICT infrastructure and the ICT training programs to foster a generation of technology literate teachers and students.

\section{Implications at the Teacher Level}

Increased efficiency in ICT skills: Lack of ICT knowledge was found as one of the major reasons for selection of technology by teachers. In other words, it is usually due to limited ICT skills that teachers resist against the implementation of ICT not because of didactics reason.

Teacher motivation and reward: Motivation is a key factor in integration of ICT by teachers. If teachers receive support and encouragement by the administrators, they feel more motivated and committed (Andersson \& Grönlund, 2009). However, for administrators to deal with the issue of ICT implementation, they should have an appropriate knowledge of it which is currently missing in Libyan institutions but they are progressively trying to develop an understanding of the technical, financial, pedagogical, and administrative dimensions of ICTs in education.

Professional development: Teacher training programs should evolve and give way to new concepts of individual and lifelong learning. One of the most critical skills for teachers in this century is the ICT skill which primarily makes them more confident. However, teachers should update their ICT skills as well as their pedagogical knowledge to be successful.

The current training programmes especially in some developing countries like Libya are very rigid and are fed by the Ministry of Education. However, it is suggested that the incorporation of more school-based programs which can be modified according to particular needs of teachers would be more beneficial. In fact, these programs should instruct teachers how to upgrade knowledge and skill. It is also important for these programs to include teacher training for ICT because the training programs of teachers are not suitable for engaging teachers in the use of ICT for preparing their lessons or for teaching in hand materials (Becta, 2004, p. 51) because the training programs only concentrate on the development of ICT skills rather than the pedagogical aspects of ICT (Becta, 2004). According to Kirkwood and Price (2006), there are two ways to modify the current professional development policies and practices. First, professional development activities should take a holistic approach to development include all stakeholders involved including not only teachers but also teacher educators, senior university managers, etc. Second, the focus should be shifted to underlying pedagogical practices and their impact in a specific educational setting.

\section{Implications at the System Level}

Traditional system of schooling: Sometimes education systems do not align with ICT and this impedes the effective use of investments in ICT. Developing countries such as Libya which are quite strict in their cultural and religious orientations do not easily give way to more innovative approaches. However, "to improve the teaching 
and learning processes, meet the changes in the education market, and satisfy the needs of learners and the community, higher education institutions in Libya have no option but to move with the times and adopt e-learning" (Rhema \& Miliszewska, 2010, p. 435).

Impacts on teaching methodology: Introduction of ICT into schools occurred during the last decade. Although, adoption of technology is now compulsory in some educational settings in developed countries, its implementation in developing countries such as Libya is still in its early stages. In fact, the effectiveness of ICT is implemented through its quality and quantity tutoring goals. To this end, organizations should support the new educational methods and practices; otherwise, the conventional methods would not change.

Most of the teachers in this study held positive attitudes towards technology so they are ready to adopt it gradually. The findings of this study as well as the other studies reviewed show that only basement for deep improvements in methodology have been laid and teachers have not yet fully accepted new ICT-based pedagogical practices. (Underwood, 2006).

Curriculum and material development: ICT is integrated into the curriculum progressively. Most the developed countries' teachers already prepare their materials by ICT so the many benefits of ICT has already been proved. ICT can in fact save time by enabling teachers through more cooperation and sharing teaching plans with other teachers with makes preparing lessons easier and faster (Becta, 2006, p. 37).

\section{Sociocultural Considerations}

Traditions, social, and cultural values are major constructs in the structure of every society. These values also play a significant in education system of every country. It is argued that "National and cultural identities play an important role in interaction with computer-based learning materials" (Huwail, Sharhan, \& Hunayyan, 2007, p. 4). Some scholars such as Dunbar (1991) believe that technology is encoded with the features of the societies which developed it. For instance, software developed in the United States, promote hidden individualistic values which are in contradiction with Islamic values. Therefore, sociocultural and religious values are sensitive issues to be considered by material developers who adapt e-learning. Thus, localization of materials adopted for teaching and learning in ICT-enhanced education systems is of high importance.

Another important point to consider is that Libyan families are still traditional and highly follow their cultural and religious values, they cannot follow most technological advances, and are not aware of the potentials of elearning. Besides, the level of English is still and this makes the use of technology limited to those who understand English well. Thus, language as another barrier to the implementation of ICT in Libya should be considered (Rhema \& Miliszewska, 2010). The above arguments imply that ICT should be adopted and implemented into education with serious precautions so as not to overthrow the ultimate aims of education.

\section{Directions for Future Research}

The current findings suggest that teachers have already passed the Persuasion stage of Roger's innovation theory and now have decided to incorporate it but it is not yet clear if they use ICT to improve their teaching. So, conducting more research to identify for what purposes teachers use ICT requires more investigation.

Moreover, since the topics addressed in this study are understudied in the context of Libya, future studies can address factors related to variations in access to technology, teaching and learning approaches, cultural expectations, and the required adaptations, to name a few.

Above all, to achieve generalizable findings that can be applied across the country, the quantitative and qualitative data found through such case studies would not suffice, and administering large-scale national studies would be needed.

\section{REFERENCES}

Abukhattala, I. (2016). The Use of Technology in Language Classrooms in Libya. International Journal of Social Science and Humanity, 6(4), 262-267. https:/ / doi.org/10.7763/IJSSH.2016.V6.655

Adopt. (2017). In Merriam-Webster's collegiate dictionary. Retrieved from http://www.merriamwebster.com/dictionary/adopt

Aesaert, K., \& van Braak, J. (2014). Exploring factors related to primary school pupils' ICT self-efficacy: A multilevel approach. ICT tools in Human Behavior, 41, 327-341. https:/ / doi.org/10.1016/j.chb.2014.10.006

Albirini, A. (2006). Teachers' attitudes toward information and communication technologies: The case of Syrian EFL teachers. ICT tools $\mathcal{E}$ Education, 47(4), 373-398. https://doi.org/10.1016/j.compedu.2004.10.013 
Al-Oteawi, S. M. (2002). The perceptions of Administrators and teachers in utilizing information technology in instruction, administrative work, technology planning and staff development in Saudi Arabia (Doctoral dissertation), Ohio University.

Andersson, A., \& Gronlund, A. (2009). A conceptual framework for e-Learning in developing countries: A critical review of research challenges. The Electronic Journal on Information Systems in Developing Countries, 38, 1-16. https:// doi.org/10.1002/j.1681-4835.2009.tb00271.x

Balanskat, A., Blamire, R., \& Kefalla, S. (2007). The ICT Impact Report: A review of studies of ICT impact on schools in Europe. Retrieved

from http://insight.eun.org/ww/en/pub/insight/misc/specialreports/impact_study.htm

Becta. (2004). A review of the research literature on barriers to the uptake of ICT by teachers. Retrieved on June 10, 2010 from http:/ / partners.becta.org.uk/page_documents/research/barriers.pdf

Becta. (2006). Learning platform functional requirements, conventry: Becta.

Becta. (2008). Harnessing Technology: Schools Survey 2008. Retrieved on October 20, 2011 from http://emergingtechnologies.becta.org.uk/uploaddir/downloads/page_documents/research/ht_schools _survey08_analysis.pdf

Brown, J. D., \& Rodgers, T. S. (2002). Doing second language research. New York: Oxford University Press.

Buabeng-Andoh, C. (2012). Factors influencing teachers' adoption and adoption of information and communication technology into teaching: A review of the literature. International Journal of Education and Development using Information and Communication Technology, 8(1), 136-155.

Chen, C. H. (2008). Why do teachers not practice what they believe regarding technology adoption? The Journal of Educational Research, 102(1), 65-75. https:/ / doi.org/10.3200/JOER.102.1.65-75

Collis, B., \& Moonen, J. (2001). Flexible learning in a digital world: Experiences and expectations. London: Kogan Page.

Creswell, J. W., Plano Clark, V. L., Gutmann, M. L., \& Hanson, W. E. (2003). Advanced mixed methods research designs. Handbook of mixed methods in social and behavioral research, 209, 240.

Dillman, D. A. (1978). Mail and telephone surveys: The total design method (Vol. 19). New York: Wiley.

Drent, M., \& Meelissen, M. (2008). Which factors obstruct or stimulate teacher educators to use ICT innovatively? ICT tools \& Education, 51(1), 187-199.

Dunbar, R. (1991). Adapting distance education for Indonesians: Problems with learner heteronomy and a strong oral tradition. Journal of Distance Education, 12(2), 163-174. https: / doi.org/10.1080/0158791910120203

Gordon, L. S. (2008). A preliminary investigation of disability awareness in the curriculum and teachers' attitudes toward inclusion in New York State elementary schools. New York: Teachers College Press.

Hamdy, A. (2007). ICT in education in Libya. Libya Country Report. Retrieved on September 10, 2016 from http://www.infodev.org/en/Document.412.pdf

Hatlevik, O. E., Guðmundsdóttir, G. B., \& Loi, M. (2015). Digital diversity among upper secondary students: A multilevel analysis of the relationship between cultural capital, self-efficacy, strategic use of information and digital competence. ICT tools E Education, 81, 345-353. https:/ / doi.org/10.1016/j.compedu.2014.10.019

Hew, K. F., \& Brush, T. (2007). Integrating technology into K-12 teaching and learning: Current knowledge gaps and recommendations for future research. Educational technology research and development, 55(3), 223-252. https:/ / doi.org/10.1007/s11423-006-9022-5

Hismanoglu, M. (2012). Prospective EFL teachers' perceptions of ICT adoption: A study of distance higher education in Turkey. Educational Technology \& Society, 15(1), 185-196.

Hsu, L. (2016). Examining EFL teachers' technological pedagogical content knowledge and the adoption of mobileassisted language learning: A partial least square approach. Computer Assisted Language Learning, 29(8), 12871297. https:/ / doi.org/10.1080/09588221.2016.1278024

Hu, P. J. H., Clark, T. H. K., \& Ma, W.W. (2003). Examining technology acceptance by school teachers: A longitudinal study. Information \& Management, 41, 227-241. https:/ / doi.org/10.1016/S0378-7206(03)00050-8

Huwail, N., Sharhan, S., \& Hunaiyyan, A. (2007). Learning design for a successful blended e-learning environment: Cultural dimensions. INFOCOMP Journal of Computer Science, 6(4), 60-69.

Johnson, D. G. (2004). Information technology and the goals of education: making nails for the hammer. In Johnson, D.G. (Ed.). Ethical, psychological and societal problems of the application of ICTs in education (pp. 34-41). Moscow: UNESCO Institute for Information Technologies in Education.

Johnson, R. B., \& Onwuegbuzie, A. J. (2004). Mixed methods research: A research paradigm whose time has come. Educational researcher, 33(7), 14-26. https:/ / doi.org/10.3102/0013189X033007014 
Keller, J. (2000). How to integrate learner motivation planning into lesson planning: The ARCS model approach. Florida State University.

Kirkwood, A., \& Price, L. (2006). Adaptation for a changing environment: Developing learning and teaching with information and communication technologies. The International Review of Research in Open and Distributed Learning, 7(2), 1-15. https:/ / doi.org/10.19173/irrodl.v7i2.294

Korte, W. B., \& Husing, T. (2007). Benchmarking access and use of ICT in European schools 2006: Results from Head teacher and a classroom surveys in 27 European countries. E-learning papers, 29(10), 1-6.

Lawless, K., \& Pellegrino, J. (2007). Professional development in adopting technology into teaching and learning: Knowns, unknowns and ways to pursue better questions and answers. Review of Educational Research, 77(4), 575-614. https:// doi.org/10.3102/0034654307309921

Li, N. (2002). Culture and gender aspects of students' information searching behavior using the Internet: a two-culture study of China and the United Kingdom (Doctoral Dissertation), Open University United Kingdom. ProQuest Digital Dissertations.

Liaw, S., Huang, H., \& Chen, G. (2007). Surveying instructor and learner attitudes toward e-learning. ICT tools $\mathcal{E}$ Education, 49, 1066-1080. https://doi.org/10.1016/j.compedu.2006.01.001

Lincoln, Y. S. (1995). Emerging criteria for quality in qualitative and interpretive research. Qualitative inquiry, 1(3), 275-289. https:// doi.org/10.1177/107780049500100301

Liu, J. (2009). A survey of EFL learners' attitudes toward information and communication technologies. English Language Teaching, 2(4), 101-106. http:/ / dx.doi.org/10.5539/elt.v2n4p101

Martins, C., Steil, A., \& Todesco, J. (2004). Factors influencing the adoption of the Internet as a teaching tool at foreign language schools. ICT tools $\mathcal{E}$ Education, 42(4), 220-237. https:/ / doi.org/10.1016/j.compedu.2003.08.007

Meleisea, E. (2007). The UNESCO ICT in Education Programme: Bangkok: UNESCO.

Mingaine, L. (2013). Skill challenges in adoption and use of ICT in public secondary schools, Kenya. International Journal of Humanities and Social Science, 3(13), 61-72.

Mishra, P., \& Koehler, M. J. (2006). Technological pedagogical content knowledge: A framework for teacher knowledge. Teachers College Record, 108(6), 1017-1054. https:/ / doi.org/10.1111/j.1467-9620.2006.00684.x

Nneji, B. U. (2014). Technologies in Education and the Dehumanization and Imperialization of Pedagogy: The African Perspective. Bulgarian Journal of Science and Education Policy, 8(1), 86-105.

Osei, C. D., Larbi, E., \& Osei-Boadu, Y. (2014). Multidimensional barriers to information and communication technology adoption among senior high school teachers in Ghana. International Journal of Education and Research, 2(12), 389-396.

Peralta, H., Costa, F.A. (2007). Teachers' competence confidence regarding the use of ICT. Educational Science Journal, 3, 75-84.

Rhema, A., \& Miliszewska, I. (2010). Towards e-learning in higher education in Libya. Issues in Informing Science and Information Technology, 7(1), 423-437. https:/ / doi.org/10.28945/1218

Rogers, E. M. (1995). Diffusion of innovations (1 ${ }^{\text {st }}$ Ed.). New York: The Free Press.

Rogers, E. M. (2003). Diffusion of innovations (4th Ed.). New York: The Free Press.

Rohatgi, A., Scherer, R., \& Hatlevik, O. E. (2016). The role of ICT self-efficacy for students' ICT use and their achievement in a computer and information literacy test. ICT tools $\mathcal{E}$ Education, 102, 103-116. https:/ / doi.org/10.1016/j.compedu.2016.08.001

Sarfo, F. K., \& Ansong-Gyimah, K. (2010). The perceptions of students, teachers, and educational officers in Ghana on the role of computer and the teacher in promoting the first five principles of instruction. TOJET: The Turkish Online Journal of Educational Technology, 9(3), 85-95.

Sheingold, K. (1991). Restructuring for learning with technology: the potential for synergy. Phi Delta Kappan, 73(1), 17-27.

Thomas, R. M. (1987). Computer technology: an example of decision-making in technology transfer. In R. M. Thomas, \& V. N. Kobayashi (Eds.), Educational technology - its creation, development and cross-cultural transfer (pp. 25-34). Oxford: Pergamon Press.

Thompson, A. D., \& Mishra, P. (2007). Editors' Remarks: Breaking News: TPCK Becomes TPACK! Journal of Computing in Teacher Education, 24(2), 38-64.

Tri, D. H., \& Nguyen, N. H. T. (2014). An exploratory study of ICT use in English language learning among EFL university students. Teaching English with Technology, 14(4), 32-46. 
Underwood, J. D. M. (2006). Academic dishonesty in tests and examinations. London: Qualifications and Curriculum Authority.

Usluel, Y. K., Askar, P., \& Bas, T. (2008). A structural equation model for ICT usage in higher education. Educational Technology \& Society, 11(2), 262-273.

Watson, G., Proctor, R. M., Finger, G., \& Lang, W. (2005). Education students' views on the adoption of ICT into their undergraduate learning experiences. In Proceedings of the Effective Teaching and Learning Conference 2004. Griffith Institute for Higher Education.

Yilmaz, C. (2011). Teachers' perceptions of self-efficacy, English proficiency, and instructional strategies, Social Behavior and Personality, 39(1), 91-100. https:/ / doi.org/10.2224/sbp.2011.39.1.91

Yuen, A. H., \& Ma, W. W. (2008). Exploring teacher acceptance of e-learning technology. Asia-Pacific Journal of Teacher Education, 36(3), 229-243. https:/ / doi.org/10.1080/13598660802232779

Zhou, L. (2003). Something can be done in public English. Foreign Language Teaching and Research, 3, $224-226$.

\section{http://www.ejmste.com}

